\title{
MgBr2-Mediated Electrochemical Dearomative Dihydroxylations, Hydroxycyclizations and Bromocyclizations of Indoles.
}

\author{
Ju Wu, Régis Guillot, Cyrille Kouklovsky and Guillaume Vincent*
}

Guillaume.vincent@u-psud.fr

Institut de Chimie Moléculaire et des Matériaux d'Orsay (ICMMO, UMR 8182), Equipe MSMT et Services Communs, Univ. Paris Sud, CNRS, Université Paris-Saclay, 15 rue Georges Clémenceau, 91405 Orsay, Cedex, France.

\begin{abstract}
We report an efficient and environmentally friendly electrochemical approach to perform dearomatization reactions of indoles at a constant potential in an undivided cell at room temperature. $M g B r_{2}$ is used as a redox mediator to indirectly oxidize the indole nucleus into a bromonium ion which is involved in dihydroxylation, hydroxycyclization and bromocyclization of indoles. Notably, we synthesized bromopyrroloindolines which are intermediates for the total synthesis of natural products. No organic byproducts are generated with this protocol which avoids the use of an additional electrolyte.
\end{abstract}

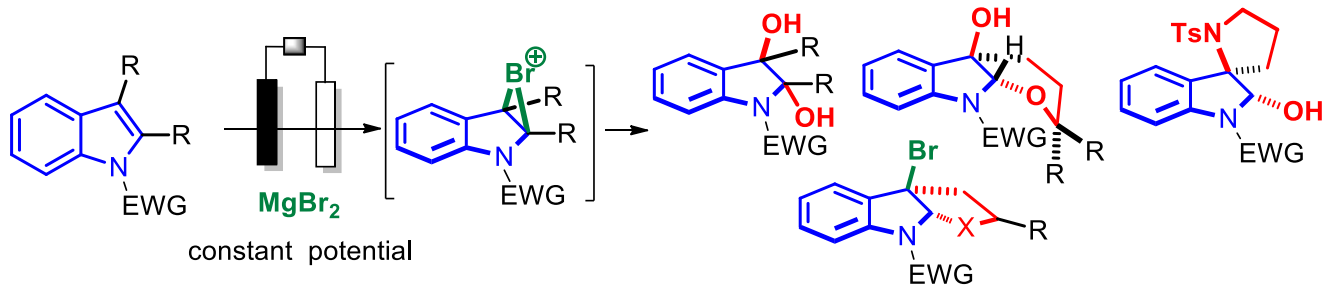

In the last decade, the resurgence of electrochemistry ${ }^{1}$ contributed to an upsurge of oxidative vicinal difunctionalization methods of alkenes in sustainable conditions. ${ }^{2}$ The related electrochemical dearomative 1,2-difunctionalization of (hetero)arenes has been less studied. In this context, our research group aims to develop dearomatization reactions of indole ${ }^{3,4}$ to generate three-dimensional indolines of potential biological relevance. ${ }^{5}$

Scheme 1. Halide-mediated electrochemical dihydroxylation of indoles.
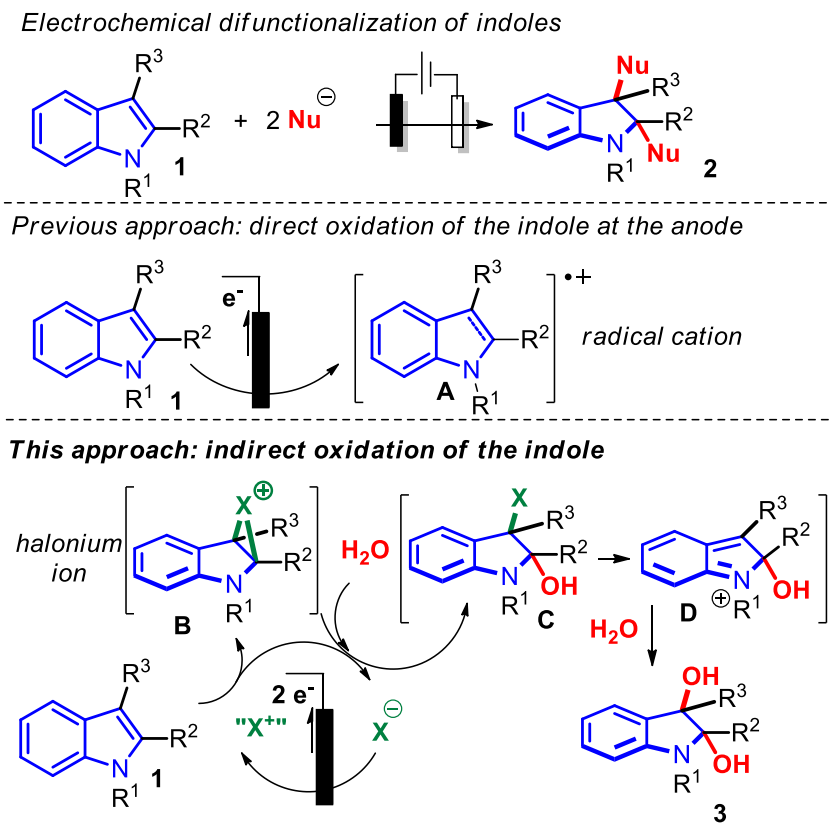

Pioneering works, albeit sporadic, demonstrated that electrochemistry could be a powerful tool to achieve the dearomatization of indoles 1 into indolines 2 (Scheme 1). ${ }^{6}$ In this vein, we recently reported a general electrochemical dearomative dialkoxylation and diazidation of indoles bearing an electron-withdrawing group on the indole 
nitrogen in galvanostatic conditions $\left(9 \mathrm{~mA} / \mathrm{cm}^{2}\right) .{ }^{7}$ As in previous works, ${ }^{6, c, c, e}$ this reaction proceeds via the direct oxidation at the anode of the indole nucleus into a radical cation $\mathbf{A}$. The direct oxidation of the substrate at the anode at a quite high potential could prevent selectivity in this oxidative process and could lead to over-oxidation reactions. We reasoned that the use of a redox mediator to indirectly oxidize the $\mathrm{C} 2=\mathrm{C} 3$ bond could allow a better chemoselectivity. Among potential electrocatalyst, ${ }^{1 a}$ we thought that halides could be efficient redox mediators via their oxidation at the anode into electrophilic species. Indeed, the anodic oxidation of halides is known and is a clean halogenation method for alkenes, alkynes or (hetero)arenes ${ }^{8}$ including indoles. ${ }^{9}$ Halides are also used as electrocatalysts in oxidative coupling reactions at the alpha position of carbonyl groups. ${ }^{10} \mathrm{We}$ reasoned that the electrophilic halide intermediate generated at the anode would selectively react with the $\mathrm{C} 2=\mathrm{C} 3$ bonds to form a halonium ion $\mathbf{B}$ which would then be opened by water. The halide of the resulting 2,3-hydroxyhalogenoindolenine $\mathbf{C}$ could then be displaced by a second molecule of water via extended imminium $\mathbf{D}$ in order to form the dihydroxylindolenine 3 .

For instance, the dihydroxylation of N-Ts-3-methylindole 1a with water ${ }^{11}$ delivered moderate yields of dihydroxyindoline 3a in our previous reported conditions at a constant current of $8.9 \mathrm{~mA} . \mathrm{cm}^{-1}$ in acetonitrile with $\mathrm{nBu}_{4} \mathrm{NBF}_{4}$ as electrolyte (Table 1, entries 1,2). Aiming at improving the yield of the dihydroxylation of $1 \mathbf{a}$ via a redox mediator, as depicted in Scheme 1, we replaced the electrolyte by halides. Among the chlorides (entries 3,4), bromides (entries 4-6) and iodides (entries 8,9) which were evaluated, $\mathrm{MgBr}_{2}$ proved to be the more promising redox mediator (entry 5). Decreasing the load of $\mathrm{MgBr}_{2}$ from one equivalent to 0.25 equivalent lead to an increase of the yield to $60 \%$ (entry 10). Conducting, the electrolysis in potentiostatic conditions (entries 11-13) instead of galvanostatic conditions led to an improved yield (70\%) at a constant potential of $5 \mathrm{~V}$ between the two electrodes (entry 12). Finally, a slight increase of the yield to $74 \%$ could be obtained, as a $4: 1$ diastereoisomeric ratio in favor of the cis diastereoisomer, with a higher concentration of water (entry 14). It should be noted that replacing $\mathrm{MgBr}_{2}$ by $\mathrm{nBu}_{4} \mathrm{NBF}_{4}$ at a constant potential of $5 \mathrm{~V}$ between the electrodes led to no reaction (entry 15) which seems to indicate that $\mathrm{MgBr}_{2}$ acts as a redox mediator. In addition to be a redox mediator, $\mathrm{MgBr}_{2}$ also acts as an electrolyte.

Table 1. Optmization of the electrochemical dihydroxylation of 1a.

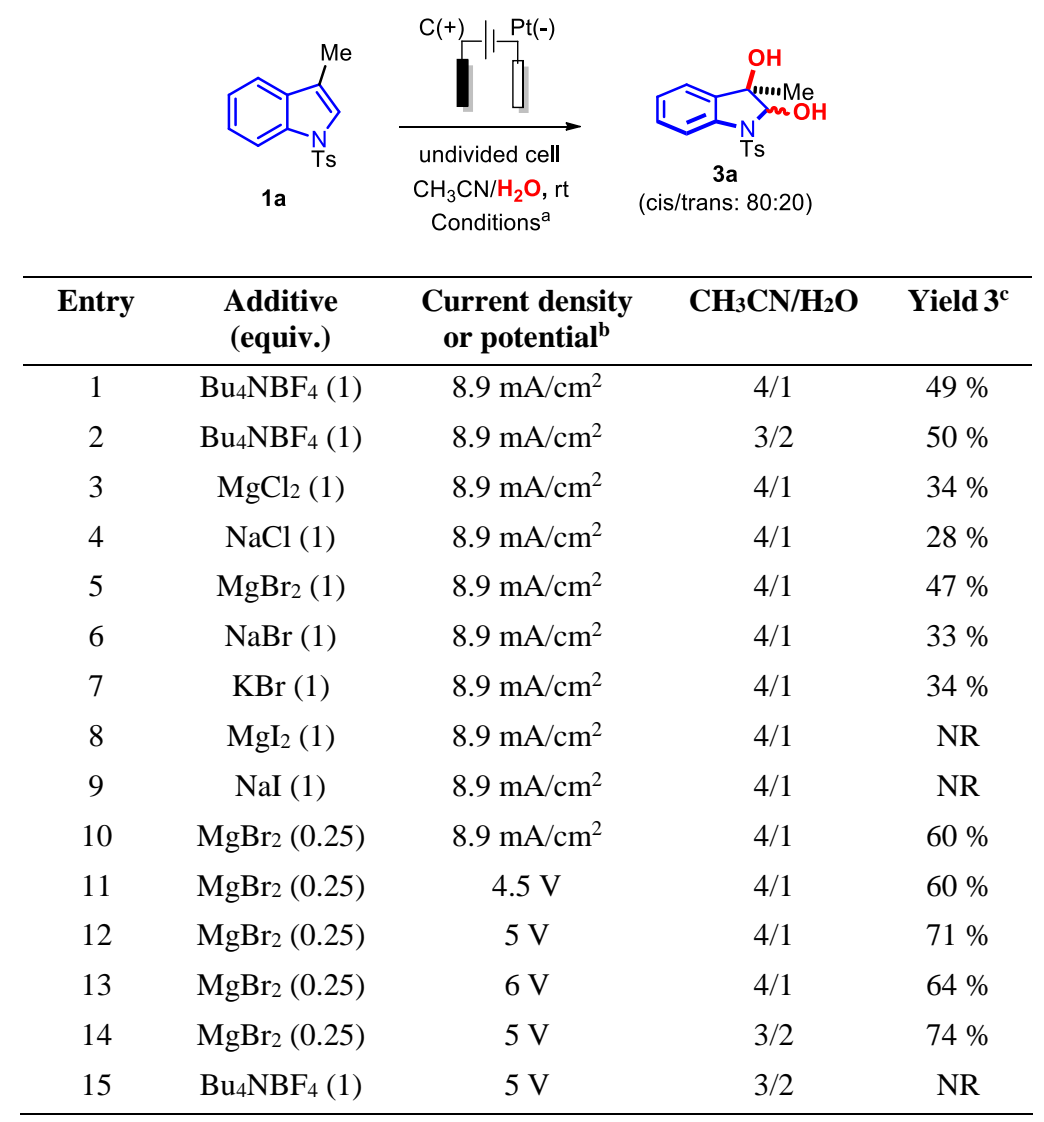

a) Undivided cell, graphite-SK50 anode $(1.4 \mathrm{~cm} \times 0.8 \mathrm{~cm} \times 0.2 \mathrm{~cm}$ submerged), platinum plated cathode $(1.4 \mathrm{~cm} \times 0.8 \mathrm{~cm} \times 0.2 \mathrm{~cm}$ submerged), 1 ( $0.2 \mathrm{mmol})$, additive, $5 \mathrm{~mL}$ of $\mathrm{CH}_{3} \mathrm{CN} / \mathrm{H}_{2} \mathrm{O}$, room temperature; b) between the two electrodes; c) Isolated yield. 
The synthesis of $\mathbf{3 a}$ was also conducted on a gram scale. Subsequently, we studied the scope of this $\mathrm{MgBr}_{2-}$ mediated electrochemical dihydroxylation reaction (Scheme 2). Switching the tosyl group born by the nitrogen of the indole to acyl groups such as acetyl, formyl and benzoyl yielded indolines 3a-c but with the trans isomer as the major product. ${ }^{11}$ At this point, we decided to continue our investigation with a tosyl as the electron-withdrawing group on the nitrogen in most cases. The substitution on the benzene part of the indole proved to be tolerant to both electron-donating, groups, halogens and electron-withdrawing groups with the formation of indoline 3e-i with the cis isomer as the major compound in almost all cases. 2,3-Unsubstituted-N-Ts-indole was also a competent substrate which delivered indoline 3j. The cis-dearomative dihydroxylation of N-Ts indoles proceeded well with various substituents at the C3-position such as alkyl groups (3k,l). 3-Cyclopropyl-indoline $\mathbf{3 m}$ was obtained with minor amounts of the opening of the cyclopropyl ring. A nitrile could also be present on the C3-alkyl side chain to deliver 3n without hydrolysis. We were also interested by the behavior of tetrahydrocarbazoles in these reaction conditions. We were pleased to observe the formation of the cis-2,3-dihydroxyindolines 3o-t which contain either electrondonating (3p), halogens (3q,r) or electron-withdrawing (3s,t) substituents. This result is in contrast with our previous direct methoxylation conditions in which $\alpha$-methoxy tetrahydrocarbolines were obtained instead of the desired 2,3-dimethoxyindolines. It proves that the $\mathrm{MgBr}_{2}$-mediated conditions are milder than our previous ones since 3o$\mathbf{t}$ did not evolved into $\alpha$-hydroxyl tetrahydrocarbolines.

Scheme 2. $\mathrm{MgBr}_{2}$-mediated electrochemical dearomative dihydroxylation of indoles.
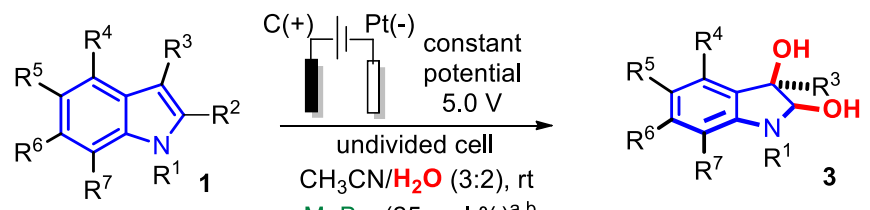
$\mathrm{MgBr}_{2}(25 \mathrm{~mol} \%)^{\mathrm{a}, \mathrm{b}}$

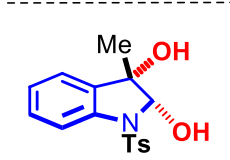

$$
\text { 3a, } 74 \%(80: 20)
$$

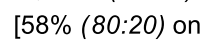

$1.28 \mathrm{~g} \mathrm{scale}^{[\mathrm{cc}]}$

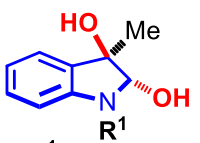

3b, $\mathbf{R}^{1}=\mathbf{A c}, 65 \%(70: 30)$

$3 \mathbf{c}, \mathbf{R}^{1}=\mathbf{C H O}, 60 \%(50: 50)$

3d, $\mathbf{R}^{1}=\mathbf{B z}, 63 \%(80: 20)$

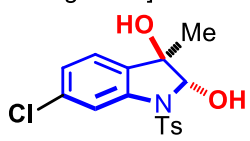

3i, 74\% (95:5)

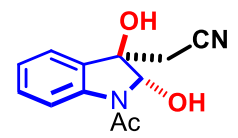

3n, $43 \%(70: 30)$
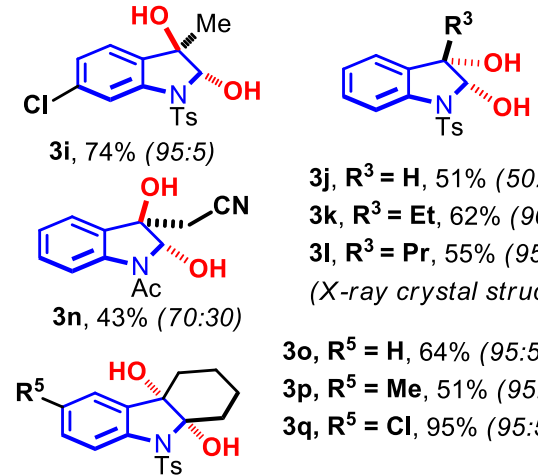

3j, $\mathbf{R}^{3}=\mathbf{H}, 51 \%(50: 50)$

3k, $\mathbf{R}^{3}=\mathbf{E t}, 62 \%(90: 10)$

31, $\mathbf{R}^{3}=\mathbf{P r}, 55 \%(95: 5)$

(X-ray crystal structure)

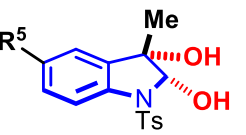

3e, $\mathbf{R}^{5}=\mathbf{M e}, 75 \%$ (80:20)

$3 \mathbf{3 f}, \mathbf{R}^{5}=\mathbf{C l}, 69 \%(80: 20)$

$3 \mathbf{g}, \mathbf{R}^{5}=\mathbf{F}, 58 \%(80: 20)$

$3 \mathbf{h}, \mathbf{R}^{5}=\mathbf{C H O}, 64 \%(80: 20)$

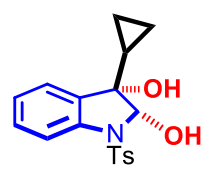

$3 m, 51 \%(95: 5)$

3o, $\mathbf{R}^{\mathbf{5}}=\mathbf{H}, 64 \%$ (95:5) $\quad 3 \mathbf{r}, \mathbf{R}^{\mathbf{5}}=\mathbf{B r}, 95 \%$ (95:5)

$3 \mathbf{p}, \mathbf{R}^{\mathbf{5}}=\mathbf{M e}, 51 \%(95: 5) \quad 3 \mathbf{s}, \mathbf{R}^{\mathbf{5}}=\mathbf{C N}, 94 \%(95: 5)$

$3 q, \mathbf{R}^{5}=\mathbf{C l}, 95 \%(95: 5) \quad 3 t, \mathbf{R}^{5}=\mathbf{N O}_{2}, 74 \%(95: 5)$

a) undivided cell, graphite-SK50 anode $(1.4 \mathrm{~cm} \times 0.8 \mathrm{~cm} \times 0.2 \mathrm{~cm}$ submerged), platinum plated cathode $(1.4 \mathrm{~cm} \times 0.8 \mathrm{~cm} \times 0.2 \mathrm{~cm}$ submerged), constant potential of $5 \mathrm{~V}$ between the electrodes, $1(0.2 \mathrm{mmol}), \mathrm{MgBr}_{2}(0.05 \mathrm{mmol}), \mathrm{CH}_{3} \mathrm{CN} / \mathrm{H}_{2} \mathrm{O}(3 \mathrm{~mL} / 2 \mathrm{~mL})$, room temperature; b) isolated yields (diastereomeric ratio of the major isomer as drawn) are indicated; c anode ( $3.4 \mathrm{~cm} \times 0.8 \mathrm{~cm} \times 0.2 \mathrm{~cm}$ submerged), cathode (3.4 cm x $0.8 \mathrm{~cm}$ x $0.2 \mathrm{~cm}$ submerged), 1 (4.5 mmol), $\mathrm{MgBr}_{2}(1.125 \mathrm{mmol}), \mathrm{CH}_{3} \mathrm{CN} / \mathrm{H}_{2} \mathrm{O}(10 \mathrm{~mL} / 6 \mathrm{~mL})$. 
Scheme 3. $\mathrm{MgBr}_{2}$-mediated electrochemical dearomative hydroxycyclization of indole derivatives.

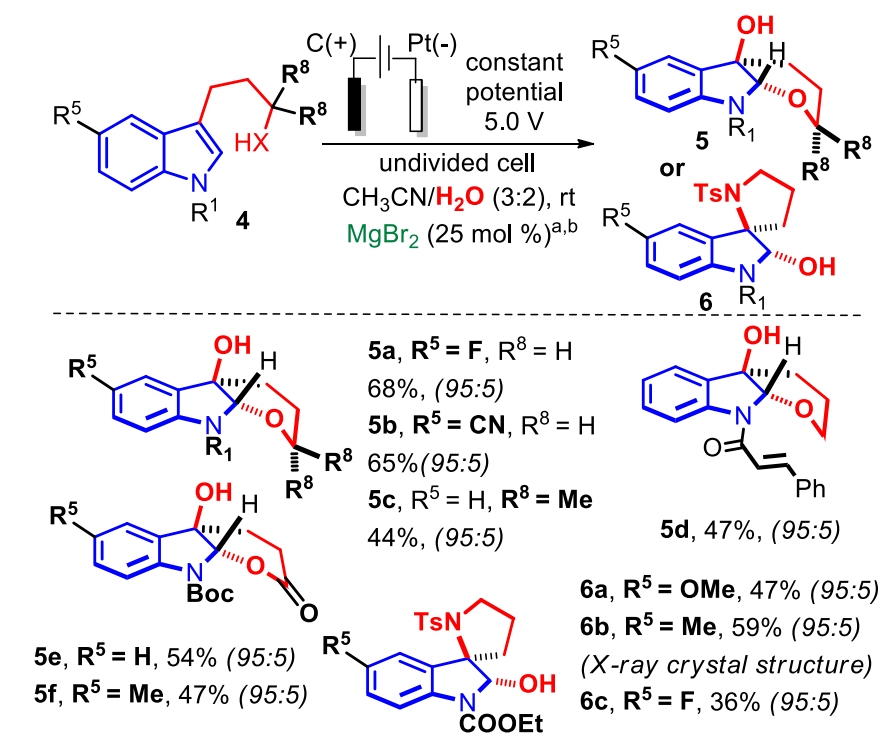

a) Undivided cell, graphite-SK50 anode $(1.4 \mathrm{~cm} \times 0.8 \mathrm{~cm} \times 0.2 \mathrm{~cm}$ submerged), platinum plated cathode $(1.4 \mathrm{~cm} \times 0.8 \mathrm{~cm} \times 0.2 \mathrm{~cm}$ submerged), constant potential of $5 \mathrm{~V}$ between the electrodes, 4 (0.2 mmol), $\mathrm{MgBr}_{2}(0.05 \mathrm{mmol}), \mathrm{CH}_{3} \mathrm{CN} / \mathrm{H}_{2} \mathrm{O}(3 \mathrm{~mL} / 2 \mathrm{~mL})$, room temperature; b) isolated yields (diastereomeric ratio of the major isomer as drawn) are indicated.

We then turned our attention towards substrates that contain a nucleophilic entity on a three carbon-side chain born by the C3-position of 4 (Scheme 3). In the case of oxygenated nucleophiles, the C2-position of the oxidized indole is intramolecularly intercepted by this nucleophile, while the C3-position is attacked by water. Hydroxytetrahydropyranoindolines 5a-d were thus obtained from indoles containing a terminal primary or a tertiary alcohol. Replacing the alcohol by a carboxylic acid led to the corresponding $\square$-valerolactones $\mathbf{5 e , f}$. In contrast, the regioselectivity was inverted with a nitrogenated intramolecular nucleophile, since 2-hydroxy-3,3-spiroindolines 6a-c were obtained via intramolecular attacked of the sulfonamide at the $\mathrm{C} 3$-position of the indole.

We did not anticipated that removing one carbon from the tether at the C3-position would lead to the cyclized 3bromo-indolines 8 rather than the expected hydroxyindolines. Indeed, the highly strained nature of the 5,5-fused extended iminium intermediate D prevents its formation. Usually the formation of such cyclized 3-haloindolines required the use of electrophilic halogen reagents. ${ }^{12}$ More recently, halides in combination with stoichiometric oxidants were also employed. ${ }^{13}$ Therefore, in order to avoid the use of a stoichiometric oxidant, we decided to study the scope of this useful electrochemical transformation using 1 equivalent of $\mathrm{MgBr}_{2}$ (Scheme 4). Tryptophol derivatives bearing various functional groups led to the formation of 3-bromofuranoindolines 8a-d. Replacing $\mathrm{MgBr}_{2}$ by $\mathrm{MgCl}_{2}$ delivered the corresponding 3-chlorofuranoindoline $\mathbf{8 e}$ albeit in a lower yield. Bromocyclisation of protected tryptamines delivered bromopyrroloindolines $\mathbf{8 f}, \mathbf{g}$. Subsequently, we decided to evaluate protected tryptophans since the resulting bromopyrrolindolines are important intermediate for the total synthesis of natural products. $^{12}$ The cyclization of diversely protected (L) and (D)-trytophan derivatives proceeded with an exo selectivity to deliver exo-3-bromopyrrolindlines 8h-l. 
Scheme 4. Dearomative halocyclization of tryptophol, tryptamine and tryptophan derivatives.

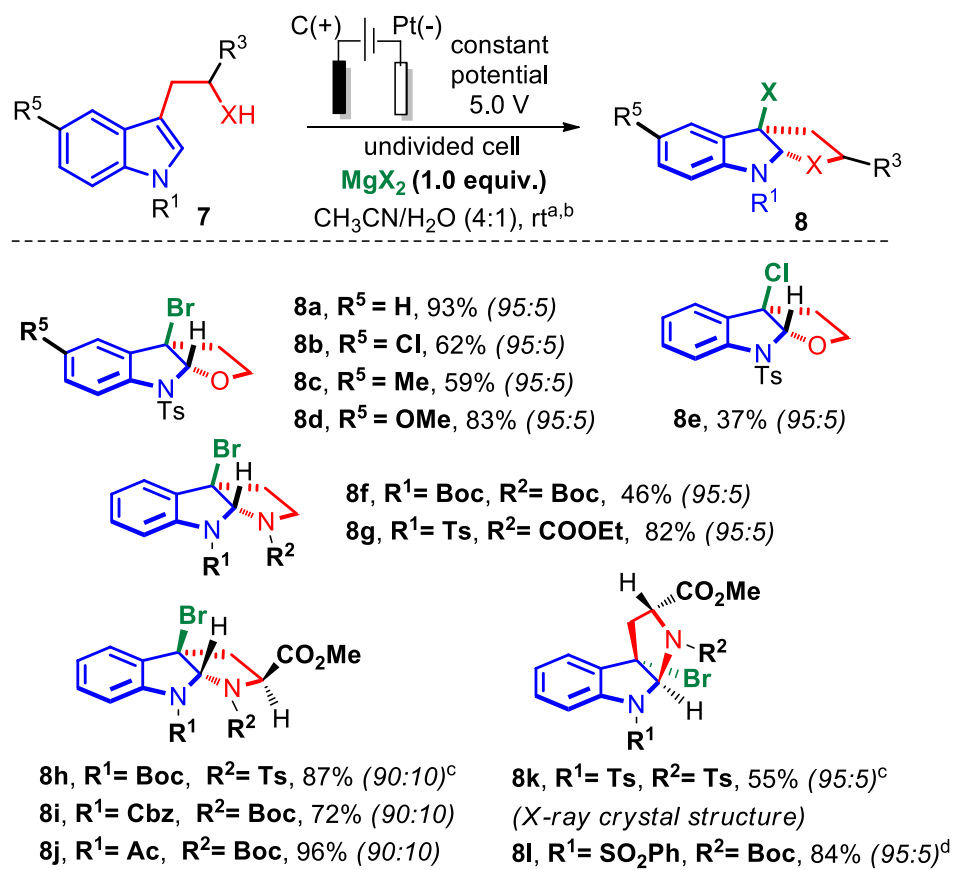

a) Undivided cell, graphite-SK50 anode $(1.4 \mathrm{~cm}$ x $0.8 \mathrm{~cm} \times 0.2 \mathrm{~cm}$ submerged), platinum plated cathode $(1.4 \mathrm{~cm} \times 0.8 \mathrm{~cm} \times 0.2 \mathrm{~cm}$ submerged), constant potential of $5 \mathrm{~V}$ between the electrodes, $7(0.2 \mathrm{mmol}), \mathrm{MgBr}_{2}(0.2 \mathrm{mmol}), \mathrm{CH}_{3} \mathrm{CN} / \mathrm{H}_{2} \mathrm{O}(4 \mathrm{~mL} / 1 \mathrm{~mL})$, room temperature; b) isolated yields (diastereomeric ratio of the major isomer as drawn) are indicated; c) on $0.1 \mathrm{mmol}$ of 7 and $\mathrm{MgBr}_{2}$ in $\mathrm{CH} 3 \mathrm{CN} / \mathrm{H}_{2} \mathrm{O}(4 \mathrm{~mL} / 1$ $\mathrm{mL})$; d) anode $(3.4 \mathrm{~cm} \times 0.8 \mathrm{~cm} \times 0.2 \mathrm{~cm}$ submerged), cathode $(3.4 \mathrm{~cm} \times 0.8 \mathrm{~cm} \times 0.2 \mathrm{~cm}$ submerged $), 7(0.6 \mathrm{mmol}), \mathrm{MgBr} 2(0.6 \mathrm{mmol})$, $\mathrm{CH}_{3} \mathrm{CN} / \mathrm{H}_{2} \mathrm{O}(12 \mathrm{~mL} / 3 \mathrm{~mL})$.

We were then eager to demonstrate the synthetic utility of the products obtained by this electrochemical halocyclization (Scheme 5). Indeed, it is well known that the bromide atom of 3-bromoindolines such as $\mathbf{8}$ could be substituted by various functional groups. Therefore, allylfuranoindoline 9 was obtained by treating bromo-furanoindoline 8a with allylsilane and AOTf. As described by Ye, exo-3-bromopyrroloindoline 81 obtained from D-tryptophan could be converted with $t$-BuOK into endo-3-indolyl-pyrroloindoline $\mathbf{1 0}$ which is an intermediate of the synthesis of gliocladins B and C. ${ }^{12 \mathrm{c}}$

Application of the electrochemical bromocyclization to (L)-tryptophan-derived diketopiperazine 11 with 2 equivalents of $\mathrm{MgBr}_{2}$ resulted in a double bromo-cyclisation to yield exo-endo compound 12 and endo-endo compound 13 in respectively $14 \%$ and $18 \%$ yields which were respectively converted by Tokuyama into (-)-epi-amauromine and $(+)$-novoamauromine. ${ }^{12 \mathrm{~d}}$ This procedure is competitive with the use of NBS by Tokuyama which required to perform the double bromocyclisation in 2 steps. 
Scheme 5. Synthetic applications.
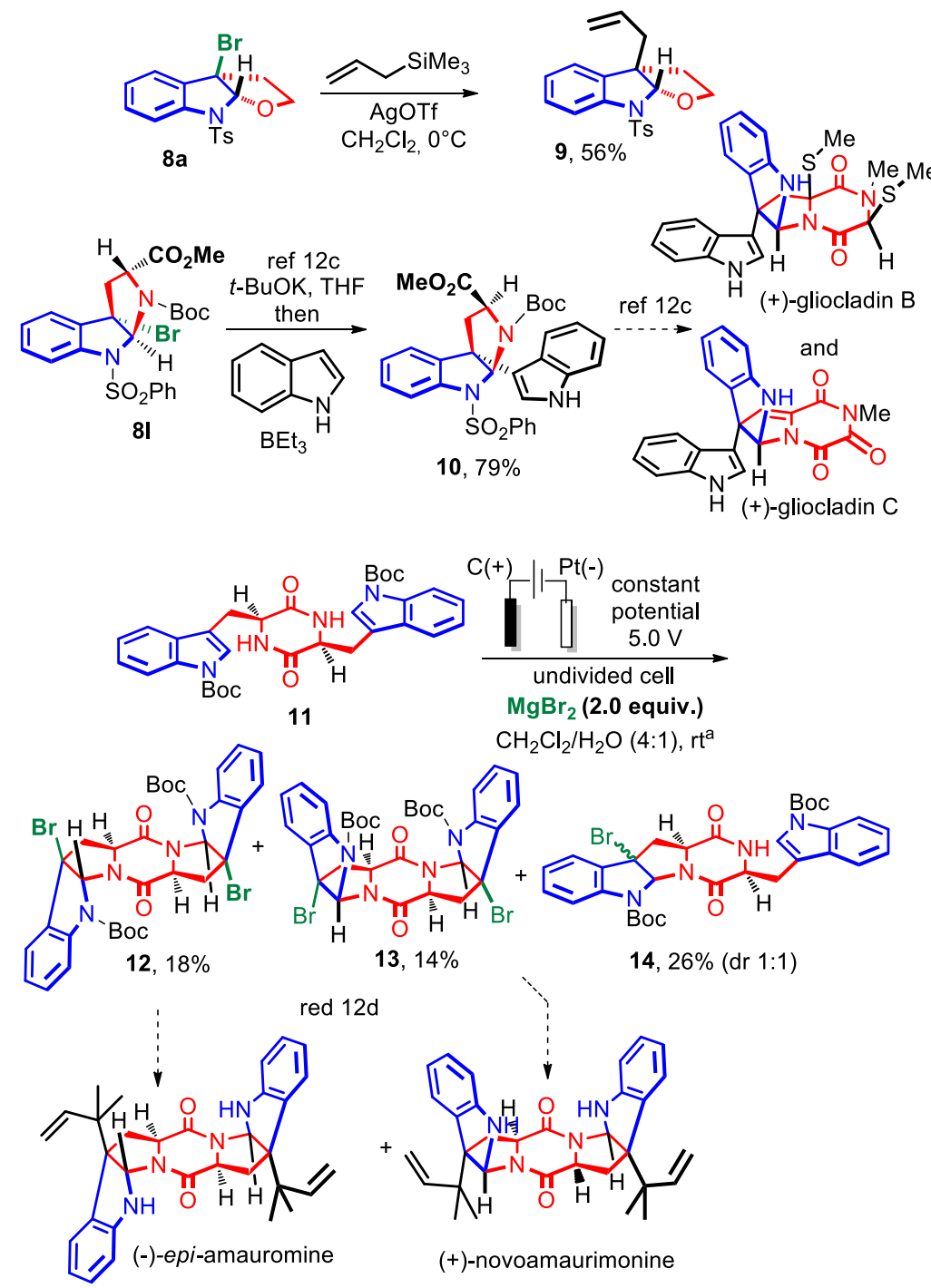

a) Undivided cell, graphite-SK50 anode $(1.4 \mathrm{~cm} \times 0.8 \mathrm{~cm} \times 0.2 \mathrm{~cm}$ submerged), platinum plated cathode $(1.4 \mathrm{~cm} \times 0.8 \mathrm{~cm} \times 0.2 \mathrm{~cm}$ submerged), constant potential of $5 \mathrm{~V}$ between the electrodes, $1(0.1 \mathrm{mmol}), \mathrm{MgBr}_{2}(0.2 \mathrm{mmol}), \mathrm{CH}_{2} \mathrm{Cl}_{2} / \mathrm{H}_{2} \mathrm{O}(4 \mathrm{~mL} / 1 \mathrm{~mL})$, room temperature.

In order to have a better understanding of the reaction, we performed cyclic votammetry $(\mathrm{CV})$ of the reactants (Figure 1). $\mathrm{MgBr}_{2}$ in pure acetonitrile showed a low current intensity however, it is possible to see oxidation peaks. ${ }^{14}$ Performing the $\mathrm{CV}$ in a mixture of acetonitrile and water $(3: 2$ or $4: 1)$ resulted in a net increase of the current intensity. It could probably be explained by the hydrolysis of $\mathrm{MgBr}_{2}$ thus liberating bromide ions in reaction mixture. As expected, the oxidation of $\mathrm{MgBr}_{2}$ occurs at a lower potential than NTs-skatole 1a. The $\mathrm{CV}$ at $500 \mathrm{mV} / \mathrm{s}$ or $100 \mathrm{mV} / \mathrm{s}$ of the mixture of $1 \mathrm{a}, \mathrm{MgBr}_{2}(25 \mathrm{~mol} \%)$ in $\mathrm{CH}_{3} \mathrm{CN} / \mathrm{H}_{2} \mathrm{O}$ confirmed that $\mathrm{MgBr}_{2}$ is oxidized first at the anode and acts as a redox mediator of the dihydroxylation reaction. For the formation of the furanoindoline $\mathbf{8 a}$ from N-Ts tryptophol 7a, we observed a similar behavior with the oxidation of $\mathrm{MgBr}_{2}$ at lower potential than $7 \mathbf{a}$. In addition and as stated before (Table 1, entry 15), no reaction occurs without $\mathrm{MgBr}_{2}$ in our reaction conditions (constant potential of $5 \mathrm{~V}$ between the two electrodes) with $\mathrm{nBu}_{4} \mathrm{NBF}_{4}$ as electrolyte. These observations rule in favor of the mechanism depicted in Scheme 1 which involved the selective oxidation of a bromide anion into an electrophilic bromide intermediate which effects the oxidation of indoles $\mathbf{1}$ or tryptophol and tryptamine derivatives 7. 
Figure 1. Cyclic voltammograms of reactants.

a)

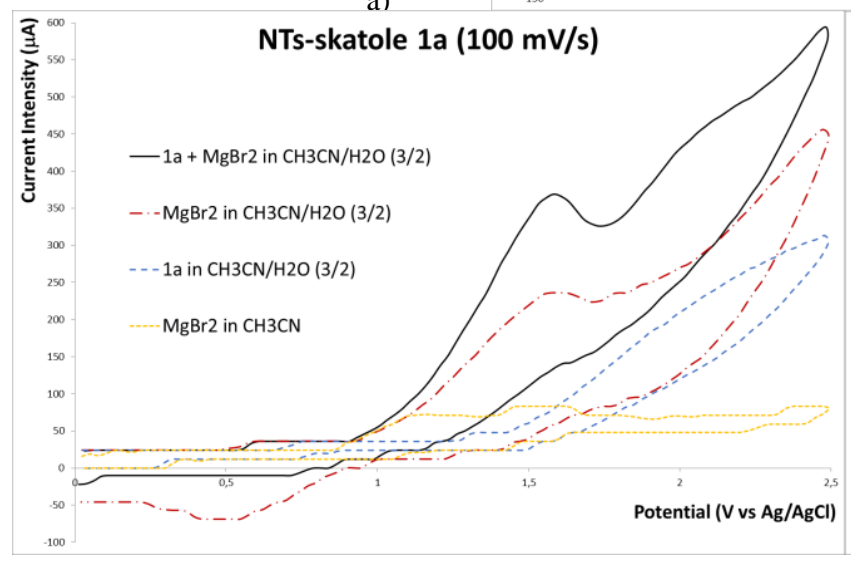

$\mathrm{N}$-Ts skatole $1 \mathrm{a}(500 \mathrm{mV} / \mathrm{s})$
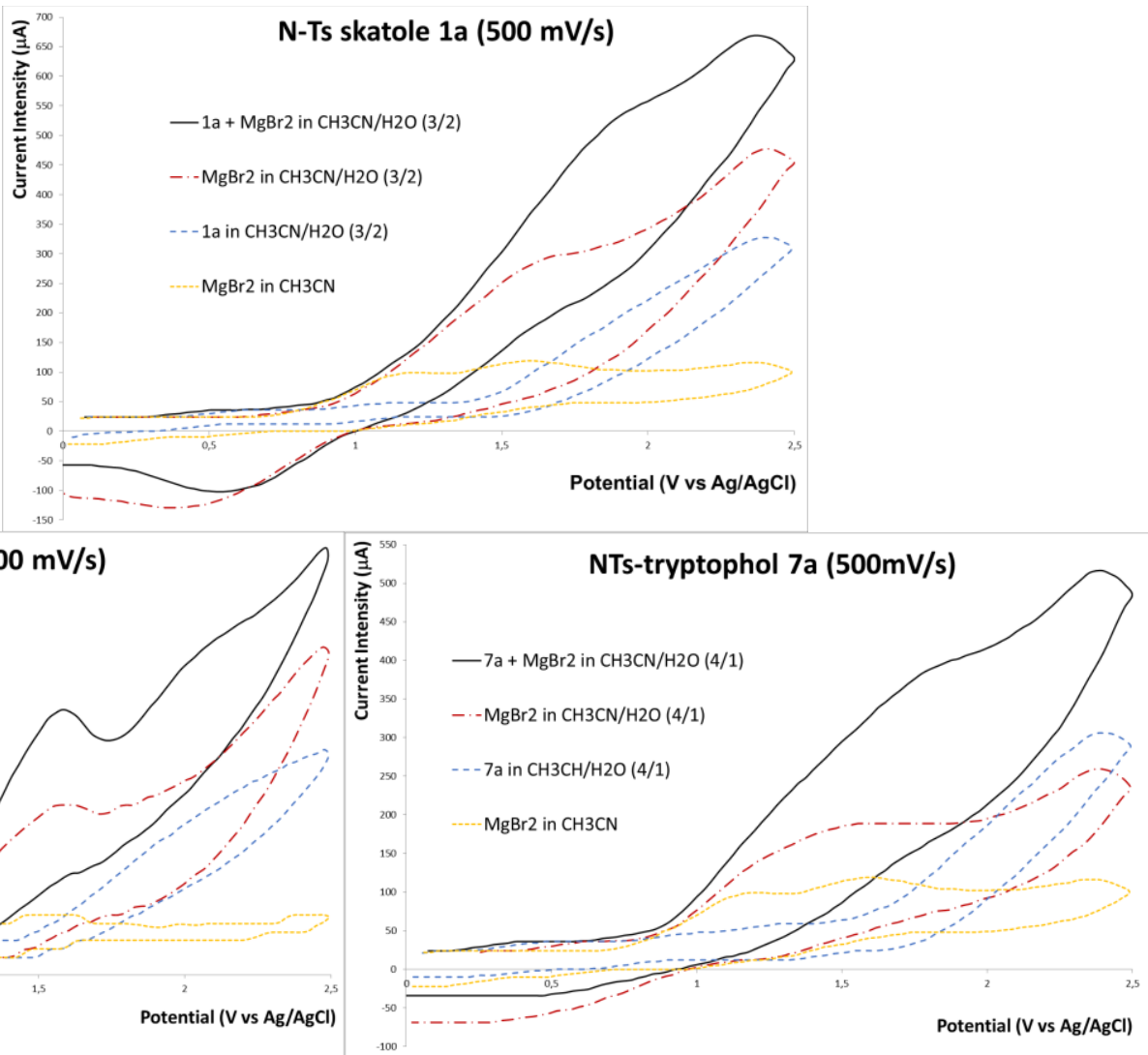

Recorded from 0 to $2.5 \mathrm{~V}$. Glassy carbon working electrode; $\mathrm{Pt}$ counter electrode; $\mathrm{Ag} / \mathrm{AgCl}$ (3M aq. $\mathrm{KCl})$ ref electrode; $0.025 \mathrm{mmol} 1 \mathrm{a}$ or 7a and/or $0.025 \mathrm{mmol} \mathrm{MgBr} 2,0.025 \mathrm{mmol} \mathrm{nBu}_{4} \mathrm{NBF}_{4}$ in $5 \mathrm{~mL}$ of $\mathrm{CH}_{3} \mathrm{CN}_{/} \mathrm{H}_{2} \mathrm{O}$ (ratio indicated on the $\mathrm{CV}$ ).

In conclusion we developed a strategy to perform the electrochemical dearomatization of indoles with a redox mediator in order to avoid the direct oxidation of the indole nucleus at the anode. The electrochemical generation of an electrophilic bromine reagent from $\mathrm{MgBr}_{2}$ leads to oxidation of the indole into a bromonium ion. Upon reaction with water, this intermediate is transformed into 2,3-dihydroxyindolines. In presence of an intramolecular nucleophile and water, hydroxycylization occurs. In the cases of tryptophols, tryptamine and tryptophan derivatives, a halocyclization took place leading to 3-bromofuranoindolines and 3-bromopyrroloindolines which are known intermediates for the total synthesis of natural products.

Guillaume.vincent@u-psud.fr

\section{Acknowledgements}

JW thanks the China Scholarship Council (CSC) for his PhD fellowship. We also gratefully acknowledge the ANR (ANR-17-CE07-0050; "ArDCo"), the Université Paris Sud and the CNRS for financial support.

\section{References}

(1) For reviews: (a) Francke, R.; Little, R. D. Chem. Soc. Rev. 2014, 43, 2492-2521. https://doi.org/10.1039/C3CS60464K; (b) Horn, E. J.; Rosen, B. R.; Baran, P. S. ACS Cent. Sci. 2016, 2, 302-308. https://doi.org/10.1021/acscentsci.6b00091; (c) Yan, M.; Kawamata, Y.; Baran, P. S. Chem. Rev. 2017, 117, 13230-13319. https://doi.org/10.1021/acs.chemrev.7b00397; (d) Wiebe, A.; Gieshoff, T.; Möhle, S.; Rodrigo, E.; Zirbes, M.; Waldvogel, S. R. Angew. Chem. Int. Ed. 2018, 57, 5594-5619. https://doi.org/10.1002/anie.201711060; (e) Möhle, S.; Zirbes, M.; Rodrigo, E.; Gieshoff, T.; Wiebe, A.; Waldvogel, S. R. Angew. Chem. Int. Ed. 2018, 57, 6018-6041. https://doi.org/10.1002/anie.201712732; (f) Jiang, Y.; Xu, K.; Zeng, C. Chem. Rev. 2018, 118, 4485-4540. https://doi.org/10.1021/acs.chemrev.7b00271.

(2) For reviews: (a) Martins, G. M.; Shirinfar, B.; Hardwick, T.; Ahmed, N. ChemElectroChem 2019, 6, $1254-1254$. https://doi.org/10.1002/celc.201801892; (b) Sauer, G. S.; Lin, S. ACS Catal. 2018, 8 (6), 5175-5187. https://doi.org/10.1021/acscatal.8b01069.

(3) For reviews: Roche, S. P.; Youte Tendoung, J.-J.; Tréguier, B. Tetrahedron 2015, 71 (22), 3549-3591. https://doi.org/10.1016/j.tet.2014.06.054; (b) Denizot, N.; Tomakinian, T.; Beaud, R.; Kouklovsky, C.; Vincent, G. Tetrahedron Lett. 2015, 56 (30), 4413-4429. https://doi.org/10.1016/j.tetlet.2015.05.078.

(4) (a) Beaud, R.; Guillot, R.; Kouklovsky, C.; Vincent, G. Angew. Chem. Int. Ed. 2012, 51, 12546-12550. https://doi.org/10.1002/anie.201206611; (b) Tomakinian, T.; Guillot, R.; Kouklovsky, C.; Vincent, G. Angew. Chem. Int. Ed. 2014, 53, 11881-11885. https://doi.org/10.1002/anie.201404055; (c) Lachkar, D.; Denizot, N.; Bernadat, G.; Ahamada, K.; Beniddir, M. A.; Dumontet, V.; Gallard, J.-F.; Guillot, R.; Leblanc, K.; N'nang, E. O.; et al. Nat. Chem. 2017, 9, 793-798. https://doi.org/10.1038/nchem.2735; (d) Ryzhakov, D.; Jarret, M.; Guillot, R.; Kouklovsky, C.; Vincent, G. Org. Lett. 2017, 19, 6336-6339. https://doi.org/10.1021/acs.orglett.7b03155; (e) Wu, J.; Nandi, R. K.; Guillot, R.; Kouklovsky, C.; Vincent, G. Org. Lett. 2018, 20, 1845-1848. 
https://doi.org/10.1021/acs.orglett.8b00361; f) Ryzhakov, D.; Jarret, M.; Guillot, R.; Kouklovsky, C.; Vincent, G. ChemRxiv, preprint. https://doi.org/10.26434/chemrxiv.7988033.v1.

(5) Lovering, F.; Bikker, J.; Humblet, C. J. Med. Chem. 2009, 52 (21), 6752-6756. https://doi.org/10.1021/jm901241e.

(6) (a) Nguyen, N. T.; Wrona, M. Z.; Dryhurst, G. J. Electroanal. Chem. Interfacial Electrochem. 1986, 199, 101-126. https://doi.org/10.1016/00220728(86)87045-0; (b) Royer, J.; Planas, L.; Martens, T.; Billon-Souquet, F. Heterocycles 2004, 63, 765. https://doi.org/10.3987/COM-03-9989; (c) Yin, B.; Wang, L.; Inagi, S.; Fuchigami, T. Electrosynthesis of Fluorinated Indole Derivatives. Tetrahedron 2010, 66, 6820-6825. https://doi.org/10.1016/j.tet.2010.06.063; (d) Ding, H.; DeRoy, P. L.; Perreault, C.; Larivée, A.; Siddiqui, A.; Caldwell, C. G.; Harran, S.; Harran, P. G. Angew. Chem. Int. Ed. 2015, 54, 4818-4822. https://doi.org/10.1002/anie.201411663; (e) Liu, K.; Tang, S.; Huang, P.; Lei, A. Nat. Commun. 2017, 8, 775. https://doi.org/10.1038/s41467-017-00873-1; (f) Fu, N.; Sauer, G. S.; Saha, A.; Loo, A.; Lin, S. Science 2017, 357, 575-579. https://doi.org/10.1126/science.aan6206; (g) Li, L.; Luo, S. Org. Lett. 2018, 20, 1324-1327. https://doi.org/10.1021/acs.orglett.8b00057; (h) Zhang, S.; Li, L.; Wu, P.; Gong, P.; Liu, R.; Xu, K. Synth. Catal. 2019, 361 (3), 485-489. https://doi.org/10.1002/adsc.201801173.

(7) Wu, J.; Dou, Y.; Guillot, R.; Kouklovsky, C.; Vincent, G. J. Am. Chem. Soc. 2019, 141 (7), 2832-2837. https://doi.org/10.1021/jacs.8b13371.

(8) (a) Fu, N.; Sauer, G. S.; Lin, S. J. Am. Chem. Soc. 2017, 139, 15548-15553. https://doi.org/10.1021/jacs.7b09388; (b) Ye, K.-Y.; Pombar, G.; Fu, N.; Sauer, G. S.; Keresztes, I.; Lin, S. J. Am. Chem. Soc. 2018, 140, 2438-2441. https://doi.org/10.1021/jacs.7b13387; (c) Yuan, Y.; Yao, A.; Zheng, Y.; Gao, M.; Zhou, Z.; Qiao, J.; Hu, J.; Ye, B.; Zhao, J.; Wen, H.; et al. iScience 2019, 12, 293-303. https://doi.org/10.1016/j.isci.2019.01.017; (d) Yang, Q.-L.; Wang, X.-Y.; Wang, T.-L.; Yang, X.; Liu, D.; Tong, X.; Wu, X.-Y.; Mei, T.-S. Org. Lett. 2019, 21, 2645-2649. https://doi.org/10.1021/acs.orglett.9b00629; (e) Sun, X.; Ma, H.-X.; Mei, T.-S.; Fang, P.; Hu, Y. Org. Lett. 2019. https://doi.org/10.1021/acs.orglett.9b00867.

(9) (a) Sun, L.; Zhang, X.; Li, Z.; Ma, J.; Zeng, Z.; Jiang, H. Eur. J. Org. Chem. 2018, 4949-4952. https://doi.org/10.1002/ejoc.201800267; (b) Sun, L.; Zhang, X.; Wang, C.; Teng, H.; Ma, J.; Li, Z.; Chen, H.; Jiang, H. Green Chem. 2019. https://doi.org/10.1039/C9GC00913B.

(10) (a) Okimoto, M.; Yamamori, H.; Ohashi, K.; Nishikawa, S.; Hoshi, M.; Yoshida, T.. Synlett 2012, 23, 2544-2548. https://doi.org/10.1055/s-00321317206; (b) Gao, H.; Zha, Z.; Zhang, Z.; Ma, H.; Wang, Z. Chem. Commun. 2014, 50, 5034-5036. https://doi.org/10.1039/C4CC01277A; (c) Liang, S.; Zeng, C.-C.; Tian, H.-Y.; Sun, B.-G.; Luo, X.-G.; Ren, F. J. Org. Chem. 2016, 81, 11565-11573. https://doi.org/10.1021/acs.joc.6b01595; (d) Qian, P.; Su, J.-H.; Wang, Y.; Bi, M.; Zha, Z.; Wang, Z. J. Org. Chem. 2017, 82, 6434-6440. https://doi.org/10.1021/acs.joc.7b00635; (e) Zhang, S.; Lian, F.; Xue, M.; Qin, T.; Li, L.; Zhang, X.; Xu, K. Org. Lett. 2017, 19, 6622-6625. https://doi.org/10.1021/acs.orglett.7b03333; (f) Wang, Q.-Q.; Xu, K.; Jiang, Y.-Y.; Liu, Y.-G.; Sun, B.-G.; Zeng, C.-C. Org. Lett. 2017, 19, 5517-5520. https://doi.org/10.1021/acs.orglett.7b02589.

(11) Kawasaki, T.; Chien, C.-S.; Sakamoto, M. Chem. Lett. 1983, 12, 855-858. https://doi.org/10.1246/cl.1983.855.

(12) For selected examples: (a) Kim, J.; Movassaghi, M. C J. Am. Chem. Soc. 2011, 133, 14940-14943. https://doi.org/10.1021/ja206743v; (b) Loach, R. P.; Fenton, O. S.; Movassaghi, M. J. Am. Chem. Soc. 2016, 138, 1057-1064. https://doi.org/10.1021/jacs.5b12392; (c) Lei, H.; Wang, L.; Xu, Z.; Ye, T. Org. Lett. 2017, 19 (19), 5134-5137. https://doi.org/10.1021/acs.orglett.7b02425; (d) Hakamata, H.; Sato, S.; Ueda, H.; Tokuyama, H. Org. Lett. 2017, 19, 53085311. https://doi.org/10.1021/acs.orglett.7b02602.

(13) (a) Xu, J.; Tong, R. Green Chem. 2017, 19, 2952-2956. https://doi.org/10.1039/C7GC01341H; (b) Tu, D.; Ma, L.; Tong, X.; Deng, X.; Xia, C. Org. Lett. 2012, 14, 4830-4833. https://doi.org/10.1021/ol302158h.

(14) Yu, L.; Jin, X.; Chen, G. Z. J. Electroanal. Chem. 2013, 688, 371-378. https://doi.org/10.1016/j.jelechem.2012.07.034. 